\title{
NURSING STUDENTS' PERCEPTION REGARDING PREDICTING FACTORS OF DRUGS USE
}

\author{
Alfonsyna Montoya de Abarca ${ }^{1}$
} Sandra Cristina Pillon ${ }^{2}$

Montoya de Abarca A, Pillon SC. Nursing students' perception regarding predicting factors of drugs use. Rev Latino-am Enfermagem 2008 maio-junho; 16(especial):607-13

The study on the perception of 264 (33.2\%) nursing students from the Professionalization and Regular groups regarding predicting factors of drugs consumption shows these students consume alcohol and tobacco and view alcohol as a leading factor in the consumption of drugs. The Professionalization group consumes tranquilizers and stimulants at a higher rate than the Regular group. The Professionalization students argue that they have to deal with an excessive personal load: career, job, family and stress. According to them, these factors motivate the consumption of tranquilizers and stimulants. The Professionalization group views the family and religion as protective factors; friends and school, on the other hand, are considered risk factors. Both groups consider drug users as amoral and addicts. The present study provides indicators that can support real actions aimed at improving the education of nursing personnel.

DESCRIPTORS: risk factors; nursing; street drugs; students, nursing

\section{PERCEPCIÓN DE LAS ESTUDIANTES DE ENFERMERÍA SOBRE LOS PREDICTORES DEL USO DE DROGAS}

Al estudiar la percepción de 264 (33.2\%) estudiantes de enfermería del grupo de Profesionalización y del grupo Regular sobre los factores que predicen el consumo de drogas entre estudiantes, se evidencia que éstos consumen alcohol y tabaco y perciben el alcohol como una propensión al consumo de drogas; el grupo de Profesionalización consume, además, tranquilizantes y estimulantes en mayor porcentaje que los estudiantes del grupo Regular. El grupo de Profesionalización percibe la familia y la iglesia como factores protectores, y de riesgo al grupo de amigos y la escuela. Igualmente, este mismo grupo considera entre las motivaciones para el uso la excesiva carga (estudio, trabajo y familia) y el estrés; percibe a los usuarios de drogas como amorales y viciosos. El factor de riesgo es la escuela, y los protectores la sociedad, la iglesia y la familia. Ese estudio nos da indicadores para replantearse acciones concretas en la formación del personal de enfermería.

DESCRIPTORES: factores de riesgo; enfermería; drogas ilícitas; estudiantes de enfermería

\section{PERCEPÇÃO DE ESTUDANTES DE ENFERMAGEM SOBRE OS PREDITORES DO USO DE DROGAS}

Ao estudar a percepção de 264 (33,2\%) estudantes de enfermagem, do grupo Profissionalizante e do grupo Regular, sobre os fatores que predizem o consumo de drogas, concluímos que estes consomem álcool e tabaco e percebem o álcool como uma propensão ao consumo de drogas. o grupo de profissionalização consome tranqüilizantes e estimulantes em maior quantidade do que o grupo do Plano Regular. O grupo de profissionalização percebe a família e a igreja como fatores protetores, enquanto que amigos e escola são considerados fatores de risco. Consideram entre as motivações para o uso, carga excessiva (estudo, trabalho e família) e estresse. Percebem os usuários de drogas como amorais e viciados. A escola é considerada fator de risco e a sociedade, igreja e a família fatores protetores. Esse estudo nos fornece indicadores para repensar ações concretas na formação dos enfermeiros.

DESCRITORES: fatores de risco; enfermagem; drogas ilícitas; estudantes de enfermagem

\footnotetext{
${ }^{1}$ MPH, RN, Full Professor, National Autonomous University of Honduras; ${ }^{2}$ PhD, Professor, University of São Paulo at Ribeirão Preto, College of Nursing, WHO
} Collaborating Centre for Nursing Research Development, Brazil, e-mail: pillon@eerp.usp.br 


\section{INTRODUCTION}

The drug phenomenon is a worldwide problem and Honduras is not an exception. International organizations ${ }^{(1)}$ point out that the most important problem in every part of the world is related to legal drugs; alcohol; tobacco and psychopharmaceuticals.

In Honduras, besides the problems with drugs, there is no general research culture, even less related to the drug phenomenon, which makes it necessary to make proposals to the higher political and technical levels in the country. The purpose of this study is to be a part of a training programme for nursing students, beginning with the identification of their perception on factors that predict drug consumption and those that they face.

When talking about risk factors, there is a reference to "personal and social circumstances, which, when related to drugs, may cause a person to start consuming"(2). The approach of these factors is directly related to their exposition, i.e., "the exposition to a factor means that, before a person reveals a problem, this person was in contact with one or more factors"(3). Consequently, it is necessary to add protective factors: school, work, family and individual factors such as self-esteem, which "although seeming like an isolated situation, it must be seen as a part of the society. As such, communication is a key item for the formation of self-esteem, which can be positive or negative" $\left.{ }^{\prime \prime 4}, 5\right)$.

According to the research, the causes for the addiction have not been identified yet, but in agreement with many studies, the decisions youngsters make to whether to consume drugs or not depends very much on the perceptions they have about drugs. Thus, this aspect has to be carefully examined in a way that its magnitude and extent can be seen, so that suitable measures can be applied.

\section{THEORETICAL MARK}

The national statistics as for illegal drugs and alcohol consumption in Honduras are only related to men. According to such statistics, $13.3 \%$ of men between 15 and 19 years old say that they have already consumed drugs once in their lives. The most common consumptions are marijuana $88.6 \%$, cocaine $31.3 \%$, "resistol" $7.2 \%$ and crack $5.9 \%{ }^{(6)}$.
Social differences are considered an important element promoting risk factors to drug users. Drug dealing corrupted institutions and public workers equally, and many Iberic-American countries. Corruption, high or low scale illegal gun dealing, delinquency and armed groups are consequences of the growing and selling of narcotics in many countries of South and Central America.

The healthcare institutions and their professionals, as actors in the process, are an important mechanism of preservation for the person's quality of life and society in general ${ }^{(7)}$. Therefore, the nurse is the professional who has more activity in this area, and has to promote their own understanding of the drug phenomenon in the social, political, economical and human contexts, with strategies contributing to overcome the problem. Therefore, the Latin-American nurse demonstrated a high social commitment, adapting to the fights that represent society's healthcare needs, promoting a process of living and being healthy. However, she is also influenced by the aforementioned group of negative factors that also bring her closer to drug consumption.

There is no general research culture in some Latin American countries, not even about the perception of risk factors by drug-users. This fact makes it necessary to develop research awareness in the nursing students' career, in a way that they may be able to help themselves, their family, the community and others by using the results and strengthening protective factors in a way that they can inhibit or limit the impact of the risk factors.

The efficiency of two teaching methods was studied in face of how nursing students evaluate relations of addiction, education, beliefs, and also their relation to alcohol consumption. The methods were applied to two groups of nursing students regarding alcoholism. The first group received lectures about alcoholism. The second group, besides lectures, had contact with people who had quit drinking many years before. Both groups improved their knowledge and beliefs; however, the second group obtained more precise information about alcoholics ${ }^{(8)}$.

Mental diseases and neurological confusion, which 400 million people suffer from, are associated with alcohol, drugs and tobacco abuses. Consequently, nurses need specific education to develop, apply and renew their knowledge and abilities to manage substance abuse and the confusion that dependency brings. The education and beliefs that nursing students have about alcohol abuse and the drug consumption are evident ${ }^{(1)}$. 
A study about the risk and protective factors, identified in adolescent consumers of psychoactive substances, was based on the public health risks related to coming closer to the causal network of certain risk and protective factors. The relations among the risk factors are complex, because they act differently in each person and on several circumstances. In any case, a result (damage) in a given sequence may, in the future, be a factor which triggers another problem in a series of events ${ }^{(9)}$.

A study lasting twenty-five years found that the relation between behavior and risk factors is related to the socioeconomic factor (income and social level); it is also a factor predicting poor health and drug abuse. The risk of having poor health and drug abuse among people with low income is three times higher than in the high income group ${ }^{(10)}$.

The abuse and confusion provoked by the substances allow the health professionals to offer healthcare to people in this situation, supporting evidences and experiences so that they can provide these people with attention effective. However, nurses are not seen, and will never be seen as a group that can make the difference between the incidence and prevalence of such confusion until they can understand and know better about the abuse of substances and its relation to health problems.

When judgments about risks, perceptions and vulnerability in different age groups are evaluated in adolescents and adults, the individual perceptions about the magnitude of personal risks involved in trying the negative results showed a relation that was inversely proportional to their ages. Most participants had either correct or exaggerated estimates about the risks ${ }^{(11)}$.

The concepts of the perception of risk are not only related to substance consumption, but also to several risk behaviors, related to sexual activities, violence or others. The perception of risk leads people to decide to act in a certain way, considering intrapersonal and environmental aspects, for or against themselves. The perception of risk is established from the person's decision to become involved or not in the consumption, beliefs, people's expectations and self-efficiency ${ }^{(12)}$.

In a study performed in Venezuela ${ }^{(13)}$ about the risk factors among adolescent students, it was found that the high-risk areas associated to drug consumption are related to family and mental health; the areas of moderate risk are recreation, behaviour and school; and those with low risk are social skills and the use of drugs.
Regarding the impact ${ }^{(14)}$ of the risk and protective factors in the development of addictive behaviour, the risk factors are related to personal variability (emotional stability), family interactions (ways of raising a person, parents' overprotection and communication difficulties), school (the adolescents trust their friends more than their family) and community (disorganization to face problems).

\section{METHODOLOGY}

This is a descriptive cross-sectional study performed in the Nursing Education Department in the College of Medical Science at the National Autonomous University of Honduras (UNAH), Tegucigalpa, Honduras. The Nursing School has 795 enrolled students; the sample of the study was made up of $264(33.2 \%)$ students in both plans of study: the Professional and the Regular Group. The study project was approved by the Biomedical Research Ethics Committee. The group of researchers was trained to collect the data. Information about the factors predicting drug consumption and the nursing students' vulnerability to these factors was included as the initial part of the self-administrated questionnaire,. For the data processing, the group worked on a databank with the SPSS 11 (Statistical Program of Social Science) for Windows.

\section{RESULTS}

Sociodemographic profile

The sample was composed by females. The average age was 35.6 for the Regular Plan and of 36.3 for the Profissionalization Plan. Among these students, $62.7 \%$ are married and another $62.7 \%$ work. The monthly wage is between two thousand to eight thousand lempiras (from US\$105.00 to 420.00), averaging 5,335 lempiras. The group that does not work was not considered. As for religion, $43.9 \%$ are Catholics, $52.3 \%$ are Protestants in many denominations and $3.8 \%$ revealed not to belong to any. The students have from one to fifteen people living in their houses, with an average of seven, for a typical standard deviation of 3.2. Among them, $44.7 \%$ live with their husbands or partners and $32.6 \%$ with their parents. 
Perception of risk and protective factors predicting the drug consumption

In the Regular Plan group, $43.3 \%$ see the family as a protective factor, in contrast with $22.6 \%$ who consider it as a risk factor, as well as the society, with equal percentage. The group of friends, at 33\%, is rated as topmost risk factor.

The Professional Group sees the family in a way similar to how the Regular Plan group does, with $38.4 \%$ seeing it as risk factor. When relating the perception of risk to other behaviours, for both groups, sexual violence reaches the first place, at 33.3\%; for the Regular Plan Group, violence represents $18 \%$. For the Professional Group, family disassociation, robberies, violations, homicides, muggings and kidnappings are in the first place, with a collective total of $58.8 \%$.

By associating religion with the protective factors, the students from the Regular Plan, either Catholics or Protestants, see the family as such in $52.6 \%$ and $31 \%$ of the cases respectively. However, it should be noted that the Catholics see the school as a protective factor, with only $3.2 \%$, contrasting with $24.2 \%$ of the Protestants.

In the Professional Group, $16.5 \%$ of the Catholics and $12.5 \%$ of the Protestants said that the school was a protective factor. The highest protective factor percentage is the group of friends: Catholics 40.9\% and Protestants $52.5 \%$. In general, both groups $(60.3 \%)$, consider people who consume drugs as addicts, and $19.3 \%$ consider them amoral.

In relation to the life context and risk and protective factors, the group of single students see the family, $22.9 \%$, as a risk factor and $38.3 \%$ as a protective factor.

Factors which predict drug consumption

This aspect identified the nursing students' vulnerability to drug consumption. For the Regular Plan group, the drugs most often consumed are tobacco $(38.5 \%)$ and alcohol $(22.7 \%)$, and, in lower percentages, tranquilizers and stimulants. From the Professional Plan Group, $27.8 \%$ consume tranquilizers and $22 \%$ consume stimulants. Therefore, $20 \%$ consume tobacco and alcohol, mentioning stress $22.1 \%$ and the school $19.7 \%$ as motivations in both groups.

In general, $98.5 \%$ perceive that alcohol consumption leads to drug consumption. As for the experiences that the nursing students had with people who use drugs, in the Regular Plan group, these experiences were lived with the family, friends and neighbours.

The Regular Plan Group considers school as a risk factor, $27.8 \%$; society, $21.7 \%$; group of friends, $23.6 \%$; as protective factors, they consider family, $36.7 \%$, and the church, $27.5 \%$. Self-esteem is seen as a risk factor within the individual factor. The Professional Plan Group sees school, 27.5\%, as a risk factor and also as an individual factor, at $25.3 \%$, including the self-esteem and the group of friends (16.7\%).

\section{DISCUSSION}

Based on the research findings, it is revealed that:

Related to the socio-demographic profile

A very young population was found, which was not expected. The Regular Plan students' age goes ranges from 20 or less to 55 years old. The data is similar to the Profissionalization Plan Group, in which only $3.2 \%$ are over 55 years old.

Among the Regular Plan students, $12.1 \%$ work on the Health Bureau as assistants. This number is considered high due to the scarceness of previous education in nursing.

The students from both Plans reveal a clear difference related to their marital status, because $55.7 \%$ from the Regular Plan are single, compared to $21.5 \%$ from the Profissionalization Plan. From the first group, $42.5 \%$ are married and from the second group, $69 \%$. This fact is understandable, since $88.4 \%$ are between less than 20 to 35 years old. It should be noted that there has been some changes in Honduras regarding women and the age of marriage (or living in a free union).

It is important to consider that both groups, Regular Plan and Professional Plan, have to work from 1 to 35 and 1 to 25 years, respectively. Nobody earns a salary over 8,000 lempiras (equivalent to US\$ 420.40), which forces some students from the Professional Plan to work permanently in two health institutions $(11.9 \%)$, i.e., 15 out of 125 . This situation does not occur in the Regular Plan because, of all students who work, they only work in a single institution, probably because they did not have 
previous training in nursing. Students in both groups have from 1 to 5 children. In the Regular Plan, 70\% do not have children and do not work; $9.5 \%$ from the Professional Plan do not have children $(n=12)$, but work.

$43.9 \%$ of the Regular Plan students are Catholic (the predominant religion in Honduras) and $52.3 \%$ belong to other Christian denominations. From the Professional Plan Group, 43.6\% $(n=55)$ are Catholics. The difference in both groups is the same: $10 \%$.

As for the nursing students perception about the factors which predict the drug consumption

The Regular Plan group notices that the family is a protective factor. However, the percentage of the replies does not reach 50\% (43.3\%), equaling 117 . However, nearly one fifth, $22.6 \%$, consider the family as a risk factor. Therefore, it can be concluded that studies related to family functions must be performed, without underestimating the remaining contexts, such as society, with equal percentages.

A study ${ }^{(13)}$ about the risk factors among students (Carabobo, Venezuela) revealed that the high risk areas, associated with drug consumption, are usually related to family, and school is among the moderate risks. As a result, family also constitutes a protective factor for the Professional Plan, but in a lower percentage, $38.4 \%$, emphasizing the difference in noticing the family as a risk factor in only $5.3 \%$. It is understood that the risk factors are diminished when the protective risks ${ }^{(13)}$ are present.

School and society also constitute risk factors: 14.6 and $17 \%$ respectively. For both groups, the group of friends is the main risk factor, 33.9 and $46.5 \%$. The differences between these percentages and the subsequent factors are very clear. However, students from both groups see people who consume drugs as addicts, totaling $52.8 \%$ and $69.2 \%$; and as amoral in 23.3 and $14.6 \%$.

This perception probably incides in the healthcare quality and in the respect that they must be given as human beings. Besides, 5.9\% see them as people who do not have the ability to cure themselves, a fact that exaggerates this situation, in a sense that the attitude of the healthcare provider is important, determining the healthcare quality.

In relation to the changes seen as favouring drug consumption for healthcare students of both groups, new substances were rated as first place, $26.6 \%$ and $28.6 \%$. As second place, there is the fact that some changes were made on the consumption model, 16 and 19\%, and the daily contact changed the perception of the problem.

As for the perception of risk related to other processes, the students mention sexual violence as well as the violence in general; family dissociation; robberies; homicides; muggings and kidnappings, as well as diseases like HIV, in higher percentages. The author $^{(12)}$ emphasizes that the conception of risk perception is not only related to the consumption of substances, but also to several risk procedures. These risks force the person to make decisions about how to act in relation to the drug consumption, an aspect which will either have a positive or negative influence.

It is worrying to see that $21 \%$ see drugs simply as another kind of medication. This perception can become a risk factor in the ability of helping others and in the prevention of drug use and abuse, even though the other $79 \%$ see drugs as psychoactive substances.

In relation to the factors that predict the drug consumption

The Regular Plan identifies as risk factors: school, $27.8 \%$; society, $21.7 \%$; and the group of friends, $23.5 \%$. The Professional Plan identifies school, with $27.5 \%$; the individual, $25.3 \%$; and the group of friends, with $16.7 \%$. These are the highest percentages observed. Besides, both groups mention, age, stress, maturity, loneliness, self-esteem and economical problems within the individual context. It is inferred that they may be referring to people under 20 years old.

As previously mentioned, it is evident that every context constitutes risk factors for both groups, with the exception of the church, $27.5 \%$; and society, with $34.7 \%$ as protective factors for the Regular Plan. For the Professional Plan, the protective factors are family, 37.7\%; and the individual context, 31.7\%. The latter can increase or reduce the risk factors identified in some measure, as Rojas says in his classification of the risk factors ${ }^{(11)}$.

It is possible to see that $45 \%$ of both groups identify normative influences as limiting drug consumption. This identification confirms that it is not enough to prevent drug use and abuse.

The family is the most powerful entity regarding risk and protective factors associated to drug consumption, in reunions where alcohol is consumed, by students who go out at night without permission, or by parents who are away from home most of the time. 
In relation to consumption, students from both groups consume legal and illegal drugs. In the Regular Plan, $38.5 \%$ consume tobacco and $22.7 \%$ consume alcohol, and also tranquilizers and stimulants in lower percentages. In the Professional Plan group, $20.1 \%$ consume tobacco and $21.1 \%$ alcohol. But this group also confesses to consume illegal drugs, such as tranquilizers, $27.8 \%$, and stimulants, $22 \%$. This can be motivated by easy access to drugs, $5.8 \%$ and $6.5 \%$, by stress, $24.3 \%$ and $19.5 \%$ in both groups, and also by overload (work, school and family).

Both groups express that drug consumption is less frequent among nursing students in the Regular Plan Group, at $70 \%$ and $60.3 \%$ from the Profissionalization Plan. However, it is shocking that $30 \%$ and $39.7 \%$ respectively, consume it regularly or very often.

Among the motivations encouraging students from both groups to consume drugs, there is the prevalence of stress and the group of friends, respectively 24.3 and $19.5 \%$ for the Regular Plan and $11.1 \%$ and $14.6 \%$ for the Professional Plan. Regarding school (continuous pressure), $19.9 \%$ for the Regular Plan and $19.5 \%$ for the Professional Plan.

According to the experience of students from both groups with other people who consume drugs, they mention the family, the group of friends and classmates. However, almost one third (32\%) of the Regular Plan students did not have any experience, as well as $1.6 \%$ of the Professional Plan.

In general, students consider that people who drink alcohol are likely to consume drugs, which is in agreement with what another study about drug consumption expresses (15) "legal drugs such as tobacco and alcohol are the front door for drug consumption".

\section{CONCLUSIONS}

The study of the drug phenomenon reveals that it is inevitable to include this component in the

\section{REFERENCES}

1. World Health Organization. Neuroscience of psychoactive substances use and dependence. Geneve: WHO; 2004

2. Fletcher RH, Fletcher SW, Wagner EH. Epidemiología Clínica. Elementos Esenciales. 3ra. Edición. Porto Alegre (RS): Artes médicas; 1996.

3. Piko B. Perceived social support from parents and peers. Which is the stronger predictor of adolescent substance use? Subst Use Mis 2000;(35):617-30. nursing students' curriculum, considering politics, international health and globalization, and with a perspective of the relation between drugs and the national policies related to healthcare. This necessity was confirmed, since the study revealed a low profile in this group regarding the drug component, and, above all, the social and economic situation found in Honduras, a country that used to be a low scale consumer and in few years reached commercialization, and became a bridge for drug access. The student will be qualified in promotion, prevention and social integration.

This study reveals the reality in which students live and develop their learning, which is taught in the school, a place they consider a risk factor. Because of this, there is the possibility for the professors of the Nursing Education Department and other parts of UNAH to take responsibility in promoting the protective factors. It is about becoming closer and knowing them better in order to work with them full time.

\section{ACKNOWLEDGEMENTS}

Acknowledgements to the Inter-American Drug Abuse Control Commission/CICAD of the SubSecretary of Multidimensional Security at the Organization of American States/OAS, the Brazilian Anti-Drugs Secretary/SENAD, faculty members at the University of São Paulo at Ribeirão Preto College of Nursing, WHO Collaborating Centre for Nursing Research Development, Brazil, to the population who participated in the studies and to the representatives from eight Latin-American countries who participated in the I and II On-Line Specialization Program for Research Capacity-Building on the Drugs Phenomenon-PREINVEST, offered in 2005/2006 by the University of São Paulo at Ribeirão Preto College of Nursing, as a distance education course.

4. Cortés LA, Aragón Díaz J. Autoestima, comprensión y práctica. Venezuela: Editorial San Pablo; 1999.

5. Burns RB. Autoconcepto: teoría medición, desarrollo y comportamiento. Bilbao, España: Ediciones EGA; 1990.

6. Secretaría de Salud. Encuesta Nacional de Epidemiología de Honduras 2001. Tegucigalpa, Honduras; 2001.

7. Prado ML. La profesión de Enfermería frente a los desafíos del fenómeno de las drogas en el Siglo XXI. El papel de las escuelas de Enfermería en el área de reducción de la demanda de drogas en América Latina. Washington: CICAD; 2003. 
8. Martínez RJ, Murphy-Parker D. Examining the relationship of addiction education and beliefs of nursing students toward persons with alcohol problems. Estados Unidos; 2003.

9. Rojas VM. Factores de riesgo y protectores identificados en adolescentes consumidores de sustancias psicoactivas: Revisión y Análisis del Sistema Actual. Lima: CEDRO; 1999. [Acceso en 2006 diciembre 14]. Disponible en: www.cedro.org. 10. Stenbacka M, Leifman A. Can individual competence factors prevent adult substance and alcohol abuse in lowand high- income areas?. Alcohol 2001;(25):107-14.

11. Millstein SG, Halpern-Felsher BL. Judgements about risk and perceived invulnerability in adolescents and young adults. J of Res on Adol 2002; 12(4):399-22.

12. Kumate RJ. Percepción de riesgo y consumo de drogas en los jóvenes mexicanos. México. Patronato Nacional de Centro de integración juvenil. México: AC; 2003.

13. Rebolledo EAO; Medina NMO; Pillon SC. Factores de riesgo asociados al uso de drogas en estudiantes adolescentes. Rev Latino-am enfermagem 2004 março-abril; 12(no especial):369-75.

14. Anicama J. Impacto de los factores de riesgo y de factores protectores en el desarrollo de la conducta adictiva. Lima: CIPMOC; 2001.

15. Programa de Prevención de las Fármacodependencias. Uso indebido del Alcohol y Drogas. Análisis del problema. Honduras: IHADFA; 2002. 